\title{
Global economic crisis and corruption
}

\author{
Artjoms Ivlevs ${ }^{1}$ and Timothy Hinks ${ }^{2}$
}

\author{
This is a pre-publication version
}

The final version:

Ivlevs, A., and Hinks, T. (2015) "Global economic crisis and corruption", Public Choice 162 (3-4): 425-445.

\section{Abstract}

We study the effects of the 2008-2009 global economic crisis on the household experience of bribing public officials. The data come from the Life in Transition- 2 survey, conducted in 2010 in 30 postsocialist economies of Central and Eastern Europe and Central Asia. We find that households hit by crisis are more likely to bribe and, among people who bribe, crisis victims bribe a wider range of public officials than non-victims. The crisis victims are also more likely to pay bribes because public officials ask them to do so and less likely because of gratitude. The link between crisis and bribery is stronger in the poorest countries of the region. Our findings support the conjecture that public officials misuse sensitive information about crisis victims to inform bribe extortion decisions.

Keywords: corruption, bribery, global economic crisis, transition economies.

JEL: D73, E32, P35.

\footnotetext{
${ }^{1}$ (Corresponding author) Department of Accounting, Economics and Finance, University of the West of England, Bristol BS16 1QY, UK. Tel: +44 11732 83943, Fax:+44 11732 82289, E-mail: a.ivlevs@uwe.ac.uk. Ivlevs is also a Research Fellow at IZA (Bonn) and is affiliated with Nottingham School of Economics (GEP), Aix-Marseille School of Economics (DEFI) and the University of Latvia (CETS).

${ }^{2}$ Department of Accounting, Economics and Finance, University of the West of England, Bristol BS16 1QY, UK. Tel: +44 11732 82741, Fax:+44 11732 82289, E-mail: timothy.hinks@uwe.ac.uk.
} 


\section{Introduction}

Few people doubt that adverse macroeconomic shocks have a profound effect on the material, psychological and physical well-being of people. Job loss, salary reduction, business bankruptcy or falling remittances introduce uncertainty and make people insecure and vulnerable, which in turn can influence different aspects of their behavior. The 2008-2009 global economic crisis is no exception: recent empirical contributions have shown that the crisis was associated with a deterioration in people's mental health (Katikireddi et al. 2012), mood, anxiety and alcohol-related disorders (Gili et al. 2013), a higher probability of committing suicide (Barr et al. 2012), falling birth rates (Sobotka et al. 2011), as well as less trust in national and supranational institutions (Roth et al. 2011). This literature, however, is in its infancy - many wider insidious effects of the crisis remain underexplored or unobserved.

In this paper, we study whether crisis can also contribute to the incidence of bribery. As yet, there is no work that analyses whether the incidence of household corruption changes with financial shocks, but there is good reason to expect that the two are connected. Firstly, in order to access public services, crisis victims may need to reveal their financial position to public officials, and this information can trigger extortion. Second, crisis victims may be willing to pay bribes to public officials to get the service quicker or make sure it is of higher quality. ${ }^{3}$

We test the hypothesis that crisis victims are more likely to bribe public officials using data on household-level corruption experience in 30 transition economies. We find that the victims of the global economic crisis are more likely to bribe public officials and, among those who bribe, the crisis victims also tend to bribe a wider range of public officials than non-victims. Concerning the reasons for bribery, we find that crisis victims are less likely to make unofficial gifts or payments out of gratitude and more likely because they are asked to do so by public officials. Our results also suggest

\footnotetext{
${ }^{3}$ See also Yamamura (in press) for the evidence that natural disasters lead to more public sector corruption at the country level.
} 
that the link between crisis and corruption is strongest in the poorest countries of the post-socialist world.

Our study makes a number of contributions to the existing literature. First, we contribute to the growing literature on the micro-determinants of household-level corruption ${ }^{4}$ and, in particular, to the links between income and bribery. Several micro-level studies have shown that richer people are more likely to pay bribes (Guerrero and Rodriguez-Oreggia 2008; Hunt and Lazslo 2012), be asked for bribes by public officials (Mocan 2008) and find corrupt behavior justifiable (Gatti et al. 2003). At the same time, Hunt and Lazslo (2012) find that, among bribers, the poor pay a larger proportion of their incomes than the rich, and Hunt (2007) finds that victims of misfortunes, such as crime, job loss, shop bankruptcy or death of an income earner, are more likely to contact public officials and be involved in bribery, once the contact with public officials has taken place. These studies point to a complex individual-level relationship between income (or other manifestations of material well-being, such as wealth and earnings) and corruption; we contribute to this debate by studying the link between the crisis-induced adverse welfare shocks and corruption.

Second, our paper contributes to the literature viewing corruption from the public choice perspective, as well as the associated policy advice. According to this literature, public officials maximize own utility and extract unofficial payments when the potential benefits from corruption outweigh the potential costs (Rose-Ackerman 1978; Klitgaard 1988). ${ }^{5}$ Poor pay of officials and the lax monitoring of performance contribute to the official's motivation to extort bribes and represent areas where policy action can be applied to reduce corruption. The results of our study reveal a particular group of people - the victims of economic crisis - who are more likely to pay bribes and be asked for bribes by

\footnotetext{
${ }^{4}$ There is also a large literature on the country-level determinants of corruption, as well as on the country- and firm-level effects of corruption. See, for example, Iwasaki and Suzuki (2012), Dreher and Siemers (2009), Serra (2006) and Yamamura (in press) for the role of country-level structural reforms, capital controls, GDP per capita, political stability, colonial past and natural disasters in determining corruption. For the effects of corruption, much effort has been devoted to finding out whether corruption has a harmful or beneficial effect on outcomes such as GDP growth and firm entry. For example, Mauro (1995), Meon and Sekkat (2005) and Johnson et al. (2011) find a harmful effect of corruption on economic growth. At the same time, Dreher and Gassebner (2013) find that corruption facilitates firm entry, and Mendez (2014) shows that corrupt officials may increase firms' compliance with regulations.

${ }^{5}$ Whether corruption persists in the long-run is open to some debate in the literature. For example, whilst RoseAckerman (1978) and Shleifer and Vishny (1993) argue that competition among officials reduces corruption to zero, this outcome depends on how powerful the central authority is (Priks 2012).
} 
public officials. The policy effort could thus be directed at identifying and monitoring interactions between public officials and the victims of the economic crisis.

Third, we use a large and as yet underexplored survey, administered in 30 economies of Central and Eastern Europe and Central Asia. An important advantage of the data is that the respondents were asked about their actual corruption experience - paying a bribe to a public official. ${ }^{6}$ Much of the previous literature on the micro-determinants of corruption has concentrated on attitudes towards corruption (Gatti et al. 2003; Truex 2011) and the probability of being asked for a bribe (Mocan 2008). Several studies (Tavits 2010; Hunt and Laszlo 2012; Hunt 2007; Guerrero and RodriguezOreggia 2008) have addressed actual bribing behavior, but only in the context of one or two countries (such as Estonia, Peru, Uganda or Mexico). To the best of our knowledge, this is the first study to focus on a direct measure of corrupt behavior - paying a bribe - in a multi-country setting. In addition to the information on actual corruption experience, the survey also contains information on why people pay bribes. This allows us to test whether crisis victims are more likely to be an extortion target of public officials.

The remainder of the paper is structured as follows. Section two presents data and variables. Section three presents and discusses the results, followed by a conclusion in section four.

\section{Data, variables and descriptive statistics}

\subsection{Data}

The data for this study come from the "Life in Transition 2" survey, conducted by the European Bank for Reconstruction and Development (EBRD) and the World Bank in autumn 2010. The survey contains nationally representative samples of either 1,000 or 1,500 respondents in 30 post-socialist countries in Central and Eastern Europe and Central Asia, and five Western European countries

\footnotetext{
${ }^{6}$ On the downside, the respondents may be reluctant to talk about the actual corruption exchanges in which they were involved. However, the stigma associated with honestly answering questions about bribery may be lower in high-corruption (such as transition economies) than low-corruption countries (such as industrialised Western democracies). This is because in high-corruption countries bribery is viewed as inevitable and part of the system (Hunt 2007).
} 
(France, Germany, Italy, Sweden and the United Kingdom). The households were selected using a two-stage clustered stratified sampling procedure: in the first stage, the frame of primary sampling units was established using information on local electoral territorial units; in the second stage, a random walk fieldwork procedure was used to select households within primary sampling units. Steves (2011) provides the survey summary, including detailed information on survey design and implementation methodology.

Our paper focuses primarily on the post-socialist countries and excludes the five Western European countries, as, in many respects, they represent a qualitatively different group from the post-socialist countries. $^{7}$ With longer histories of democracy and transparency, corruption in Western European countries is less of an issue than in Central Eastern Europe and Central Asia. Partly because of this, admitting involvement in corrupt exchanges carries a higher stigma, and therefore is less common, in Western countries than in transitional and developing countries, where corruption is endemic (Hunt 2007; EBRD 2005; Transparency International 2005). This said, we still want to compare the bribery experience of crisis victims in the East and the West, which is why we include a Western countries' group in our regional analysis of the crisis-bribery relationship.

\subsection{Variables}

The aim of the empirical part of the paper is to test the relationship between bribing behavior, on the one hand, and crisis-related variables, on the other. This subsection discusses the construction of the dependent variable (having paid a bribe) and the set of regressors - variables related to the economic crisis and the socio-demographic characteristics of the respondents.

\subsubsection{Dependent variable: having paid a bribe}

\footnotetext{
${ }^{7}$ The main dataset includes Albania, Armenia, Azerbaijan, Belarus, Bosnia, Bulgaria, Croatia, the Czech Republic, Estonia, Georgia, Hungary, Kazakhstan, Kosovo, Kyrgyzstan, Latvia, Lithuania, former Yugoslavian Republic of Macedonia, Moldova, Mongolia, Montenegro, Poland, Romania, Russia, Serbia, Slovakia, Slovenia, Tajikistan, Turkey, Ukraine and Uzbekistan.
} 
The interviewees were asked several corruption-related questions. To construct our dependent variable, we use a question which captures actual corruption behavior most directly. The question has a nested structure. First, the respondents were asked whether, in the last 12 months, they or any of their household members had contact with the following public officials/ institutions: interacting with road police; requesting official documents (visa, passport) from authorities; going to courts for civil matters; receiving public education (primary or secondary); receiving public education (vocational); receiving medical treatment in the public health system; requesting unemployment benefits; requesting social security benefits. If the answer was positive, the respondents were asked whether an unofficial payment or gift was paid to the public official. We use this information to construct two variables which capture 1) the probability of bribing at least one (any) type of public official, conditional on contact with at least one (any) public official and 2) how many types of public officials did the household bribe, if at least one bribe was paid. The first variable is dichotomous, taking the value of 1 if the respondent bribed at least one type of public official and 0 if the respondent contacted at least one type of public official but never paid a bribe; the respondents who did not have a contact with any public official (20\% of the sample) are excluded from the analysis. ${ }^{8}$ The second variable is a count variable, ranging from 1 to 8 .

\subsubsection{The regressors of interest}

One of the objectives of the "Life in Transition-2" survey was to ascertain possible effects that the global economic crisis had on the welfare of households. First, the respondents were asked : "How much, if at all, has the economic crisis affected your household in the last two years?", with possible answers "not at all", "just a little", "a fair amount" and "a great deal". Four dummy variables were created to capture each of the answers. Overall, $28 \%$ of respondents answered "not at all", $23 \%$ "just a little", 30\% "a fair amount", and 20\% "a great deal". ${ }^{9}$ Next, all respondents, except those who

\footnotetext{
${ }^{8}$ Table $\mathrm{A} 1$ of the online appendix contains information on the share of respondents who contacted a particular type of public official and the number of respondents who paid a bribe.

${ }^{9}$ This distribution of answers excludes respondents who did not provide an answer to the question $(6.6 \%$ of the sample). The crisis questions non-respondents, however, are not excluded from the econometric analysis - all regressions, looking at general effects of crisis, contain a crisis-question-missing-value dummy (results for this variable are not reported and are available on request).
} 
answered "not at all", were asked about the ways in which the economic crisis had affected household income streams. A menu of eleven items, reported in the first column of Table 1, was offered. The respondents had to indicate all items that applied to the household, and then to choose the most important one. Table 1 reports the proportions of positive answers, showing that reduced wages represented, by far, the most widespread effect of crisis (the most frequently chosen and the most important effect of the crisis ( $29 \%$ of respondents affected by crisis said reduced wages was one of the effects and $20 \%$ indicated that it was the most important effect), followed by reduced remittances (14\% and 9\%), delayed and suspended wages (13\% and 6\%), and the job loss of the household head or another household member (11\%-12\% and $8 \%)$. We created two sets of dummy variables (for "all that apply" and "the most important" answer categories, respectively) to capture different effects of the crisis. We excluded from our analysis the last three items in the list (someone who was working took on a second job; longer working hours in an existing job; someone who was not working before found a new job), as it is possible that these effects represent an improvement in the household wellbeing, while our focus is on the negative effects of the crisis. Exploring possible links between the remaining eight crisis dummies (in the "all that apply" category), we found relatively low correlations between them (see Table A2 of the Online Appendix for the correlation matrix): the most correlated were the reduced working hours, delayed/suspended wage and reduced wage dummies (the pairwise correlation coefficients ranged between 0.17 and 0.22 ), followed by the two job loss dummies (0.12). ${ }^{10}$ Given such relatively low levels of correlation and a large sample size, we jointly included the eight crisis effect dummies as potential determinants of corruption behavior.

\section{[Insert Table 1 here]}

Considering further the effects of the crisis, all of the respondents were asked what measures (if any) they had to take as the result of a decline (if any) in income or other economic difficulty. A menu of 19 possible answers, ranging from "reduced the consumption of staple foods" to "forced to move",

\footnotetext{
${ }^{10}$ These coefficients are Pearson correlations. We have also calculated tetrachoric correlations (a technique suitable for calculating correlations between dichotomous variables); they did not exceed 0.35 . In addition, we have tested for multicollinearity by obtaining the Variance Inflation Factors (VIF) after estimating the model. The VIFs for the different effects of crisis ranged from 1.03 to 1.24 , being well below the critical value of 10 .
} 
was offered; respondents could choose multiple answers. Table 2 shows that, as a result of a decline in income or other economic difficulty, more than a third of all respondents had to reduce the consumption of staple goods and $45 \%$ had to reduce the consumption of luxury goods. Reduced consumption of alcohol, use of own car, vacations, as well as delayed utility payments, were reported by $16 \%-23 \%$ of respondents. Between $10 \%$ and $13 \%$ of all respondents said that they had to postpone/ skip visits to the doctor, stop buying medication and reduce tobacco smoking.

[Insert Table 2 here]

The correlations between different measures reported in Table 2 do not exceed 0.31 (see Table A3 of the online appendix for the correlation matrix); this might justify the joint inclusion of the corresponding dummies into the same regression. However, to reduce the number of regressors, we created several composite dummy variables by merging 1$)$ alcohol and tobacco measures ( 1 if reduced either alcohol or tobacco, or both, 0 otherwise); 2) the three education-related measures; 3) the three healthcare-related measures; 4) the three utilities-related measures; and 5) the measures related to loan repayment, asset selling and being forced to move. The help-to-relatives measure was excluded from our analysis since it is likely to capture the effects of crisis on the well-being of other households. We were left with nine dummy variables capturing adverse effects of crisis on household expenditure and standard of living. They are jointly included in regressions as potential predictors of household corruption experience. ${ }^{11}$

\subsubsection{Socio-demographic controls}

Following the empirical literature on the micro-determinants of bribery (Tavits 2010; Guerrero and Rodriguez-Oreggia 2008; Hunt and Lazslo 2012; Hunt 2007; Truex 2011; Ivlevs and Hinks 2014), our regressions include the following socio-demographic controls (see Table A4 in the online appendix for summary statistics): dummy variables for gender, six age groups, linguistic minority status and three education levels (primary, secondary, tertiary). To capture household income, we use

\footnotetext{
${ }^{11}$ The post-estimation Variance Inflation Factor analysis, again, suggests that the multicollineraity is unlikely to be an issue: VIFs for the expenditure effect variables ranged from 1.08 to 1.35 , which is lower than the critical value of 10 .
} 
information on a self-reported (subjective) position on an imagined ten-step income ladder, ${ }^{12}$ which we convert into five income ladder dummies (the first dummy captures steps 1 and 2, the second 3 and 4, and so on). In addition, we include a wealth index, created using the information on household assets (car, secondary residence, bank account, debit card, credit card, mobile phone, computer and internet access at home). ${ }^{13}$ Further controls include dummy variables for being employed and three types of geographical locations (rural, urban, and metropolitan).

Finally, to control for all unobserved country-wide influences (such as historical and cultural) on individual corruption behavior, all regressions include country-fixed effects.

\section{Results}

\subsection{Main results}

We estimate the probability of bribing (any type of) public official with binary probit and the relationship between being a crisis victim and the number of different public officials bribed with OLS. ${ }^{14}$ At the outset, we want to mention that our results should be interpreted as conditional correlations rather than causal effects. Endogeneity could arise if particular groups of households are more likely to be victims of crisis and, at the same time, pay bribes to public officials (omitted variable bias). Unfortunately, the cross-sectional dataset we use does not contain variables that could serve as instruments for being a crisis victim. At the end of this section we discuss the ways and measures taken to mitigate possible endogeneity of the crisis variable.

\footnotetext{
12 The respondents were asked, "Please imagine a ten-step ladder where on the bottom, the first step, stand the poorest $10 \%$ people in our country, and on the highest step, the tenth, stand the richest $10 \%$ of people in our country. On which step of the ten is your household today?"

${ }^{13}$ The wealth index was constructed using principal component analysis. Unfortunately, the survey does not contain information on the actual household (or individual) income. We considered using information on household expenditures on different goods (food, utilities, transport, education, health, clothing and durable goods) as a proxy for household income, but decided against it, as the "do not know"/ non-response rate for several of these expenditure categories is as high as $18 \%$ (and much higher for particular countries - e.g., $66 \%$ missing answers for the expenditure on durable goods in Uzbekistan), and the proportion of missing values of the composite expenditure variable is $46 \%$.

${ }^{14}$ We have also estimated the model with Poisson regression; the results are consistent with the OLS model and are available on request.
} 
We start with estimating our models for the whole sample of Central Eastern European and Central Asian countries, focusing both on the general effects of crisis (Table 3) and the impacts of crisis on specific income streams and expenditures (Table 4). Next, we analyze the reasons for bribing public officials (Table 5). To check the sensitivity of the results, we run the models for different geopolitical blocs (Table 6) and for countries with different income levels (Table 7). Finally, we estimate the model for different types of public officials (Table 8).

Table 3 reveals the characteristics of people who bribed at least one public official (column 1) and the determinants of the number of public officials bribed (column 3); these benchmark estimations exclude the crisis-related variables. The results suggest that women are less likely to pay bribes and, on average, women bribe fewer officials than men. Relative to the reference age group 35-44, people aged 18-25 and 55+ are less likely to bribe and, among bribers, people aged 25-30 and 44+ bribe fewer public officials than the reference group. Subjective income position matters for the probability of bribery: people positioning themselves at the top of the income distribution are more likely to bribe than those at the bottom. The coefficient of wealth points in the same direction: wealthier people are more likely to bribe and, among bribers, wealthier people bribe a wider range of public officials. These results confirm the general finding in the literature that, within a particular country, wealthier people are more prone to corruption (Hunt and Laszlo 2012; Guerrero and Rodriguez-Oreggia 2008; Mocan 2008). Possible explanations are the higher opportunity costs of wealthier people who are willing and able to pay public officials for a quicker and better service, or the propensity of corruption-prone officials to target people with higher incomes. ${ }^{15}$ Among people who pay bribes, those living in rural and metropolitan areas tend to bribe a wider range of public officials; these groups, however, are not necessarily more likely to pay bribes in general.

\footnotetext{
${ }^{15}$ We have also checked for possible non-linearities in the wealth-bribery relationship, by estimating the models with the wealth index and its square. The results suggest an inverted U-shaped relationship, with the implied inflection point equal to 2.89 and 1.34 on the wealth index scale for the models explaining general bribery and the number of officials bribed, respectively. It is should be noted that only two percent of respondents had a wealth indexes above 2.89 and those of 15 percent exceeded 1.34 . This effectively means that, for the overwhelming majority of our sample, the likelihood of bribery and the range of public officials bribed was increasing with household wealth.
} 
Four dummy variables capturing general effects of the crisis are introduced in columns 2 and 4 in Table 3. The results suggest that crisis victims are more likely to bribe. Compared with households who were "not at all" affected by crisis (the reference group) and keeping other factors constant, those affected by crisis "just a little", "a fair amount" and "a great deal" are 6.0, 7.4 and 8.9 percentage points, respectively, more likely to have bribed at least one public official. Among people who bribed, those affected by crisis "just a little", "a fair amount" and "a great deal" bribed, on average, 0.08 , 0.145 and 0.204 more public officials than the non-victims.

[Insert Table 3 here]

In Table 4, the dummy variables capturing general effects of crisis on the household welfare are replaced with dummy variables capturing the eight specific adverse effects on the households' income streams. In specification [1], each household is allowed to report multiple effects of the crisis on its income streams. The results suggest that crisis-related job losses, closures of family businesses, reduced working hours, as well as delayed, suspended or reduced wages, are associated with a 3.0-4.5 percentage points higher probability of bribing public officials. Migration-related variables are also important predictors of bribery: the reduced flow of remittances and the return of a migrant are associated with 4.6 and 5.8 percentage points higher probabilities of bribery.

Specification [2] of Table 4 replaces the variables capturing various effects of the crisis on household income streams with the variables capturing the most important effects. We obtain statistically significant coefficients for all crisis-related dummies, which have larger, ranging from 5.4 to 9.2 percentage points, marginal effects than specification [1]. The smaller marginal effects in specification [1] are to be expected, as it uses overlapping variables to capture the effects of the crisis. Specification [3] of Table 4 replaces the income effects of the crisis with the expenditure effects. With the exception of reduction in the purchases of staple goods, alcohol and tobacco, the coefficients of all 
variables are statistically significant, with the marginal effects ranging from 2.7 to 6.3 percentage points.

The crisis-related correlates of the number of public officials bribed are reported in columns [4]-[6] of Table 4. With the exception of returned migrants in column [5], all crisis-related effects on income streams are associated with bribing a wider range of public officials. The coefficients of the crisis effects on several expenditure categories are also significant (column [6]). The estimate is the largest for the education variable (households whose education activities were affected by crisis bribed, on average, 0.196 more public officials). This is not surprising, as withdrawal from university, training or enrollment in further education implies a change in one's activity status and necessitates contact with a broader range of public officials.

\section{[Insert Table 4 here]}

\subsection{Crisis and reasons for bribery}

Earlier we suggested two reasons why crisis victims would be more likely to bribe than non-victims. First, crisis victims may have to reveal sensitive information to public officials - income level, savings, occupation, return of a household member from abroad - helping public officials to decide whether to extort and, if so, how much. Second, being hit by a shock (e.g., crisis-induced family business closure) and wanting to get back on track quickly, crisis victims may be more likely to offer bribes than the average user of public services.

The Life in Transition-2 survey contains information on the reasons for paying bribes, which we can use to test whether crisis victims have different reasons for bribery than non-victims. In particular, those individuals who reported bribing public officials were asked a follow-up question: "Why did you make an informal payment for services you should have received for free?" Possible answers included "I was asked to pay" (28\% of respondents provided this reason), "I was not asked to pay but I knew that an informal payment was expected" (29\%), "I offered to pay, to get things done quicker or 
better" (19\%), and "I was not asked to pay but I wanted to express my gratitude" (19\%); 5\% of respondents refused to answer. Given the unordered nature of answers, we study the determinants of various reasons for paying bribes in a multinomial logit model. Only the respondents who bribed are taken into account. As the reasons for bribing were provided for each type of bribed public officials (rather than for paying bribes in general), we follow Hunt (2007) and Ivlevs and Hinks (2014) to generate a stacked dataset of household-official pairs. To control for possible interdependence of responses provided by the same respondent, and to account for different types of institutions/officials, we cluster standard errors at the household level and include dummy variables for each type of public officials.

The results, reported in Table 5, suggest that the crisis victims and non-victims are equally likely to report that they made an informal payment because they knew it was expected or because they wanted to get things done quicker and better. However, people affected by the crisis 'a great deal' were 6.8 percentage points more likely to be asked for a bribe by public officials, and people affected by crisis 'a fair amount' and 'a great deal' were 2.5 and 5.3 percentage points, respectively, less likely to pay bribes out of gratitude, relative to households that were not affected by the crisis. This finding supports the hypothesis that public officials have access to sensitive information about the crisis victims, making them an easy extortion target. ${ }^{16}$ The finding is, however, attenuated by the households who were affected by crisis 'just a little'. Relative to households that were not affected by the crisis, they are 3.3 percentage points less likely to be asked for bribes. This might suggest a nonlinear relationship between the degree to which households were affected by crisis and different motivations to make informal payments. In a sensitivity check, we have replaced the four general effects of crisis with a combined category affected 'a fair amount' and 'a great deal', keeping a combined category 'not at all' and 'just a little' as a reference group. The results point in the same direction: relative to the reference groups, households affected by crisis at least "a fair amount" are

\footnotetext{
${ }^{16}$ This finding, however, should be interpreted with caution. Some people habitually complain about everything, including being the crisis victims and the extortion targets for public officials. Unfortunately, with the present data, we are not able to isolate such potential "kvetching" effects (Kaufmann and Wei 2000 p.16); the use of longitudinal data, which would allow isolating unobserved personality trait effects, represents a possible solution and a way forward.
} 
3.8 percentage points more likely to bribe because public official ask them to do so and 3.4 percentage points less likely to bribe out of gratitude; the marginal effects for all the other motivation categories are statistically insignificant.

[Insert Table 5 here]

\subsection{Sensitivity checks}

The post-socialist economies of Central and Eastern Europe and Central Asia are far from being a homogenous group. Substantial differences exist in income levels, historical and cultural paths, current political regimes and institutions. Given such heterogeneity, one could hypothesize that the strength of the link between corruption and crisis depends on country-level characteristics. In particular, in those countries where public officials are less well-off than others in society or relative to public officials in the richest countries in the region, there may be a greater likelihood of these officials extorting money from crisis victims. In this subsection, we take a closer look at the link between corruption and economic crisis and whether this link differs between regions, and test its possible dependence on country GDP per capita.

We start by estimating our model for different geopolitical regions. Along with a number of country blocs within the post-socialist region, we include, for comparison, estimations for the group of five Western European countries (the United Kingdom, Germany, Italy, Sweden and France), ${ }^{17}$ information on which is also available in the 'Life in Transition-2' survey. Panel I of Table 6 reports the results for the probability of bribery, revealing that crisis victims are more likely to pay bribes in all country groups except the Baltics. The largest association is observed in Central Asia, where households affected by crisis 'a great deal' are 27 percentage points more likely to bribe public officials than non-victims.

\footnotetext{
${ }^{17}$ In this paper we concentrate on the effects of crisis on the likelihood of bribery, controlling for individuallevel characteristics. The discussion of these individual-level characteristics on bribery in Western Europe can be found in our related work (Ivlevs and Hinks 2014).
} 
As a sensitivity check, we have merged dummies 'affected a fair amount' and 'a great deal into one category, keeping the combined category 'not at all' and 'just a little' as a reference group. The results, reported in Panel II of Table 6, confirm that the households affected by crisis to a greater extent are more likely to pay bribes in the Balkans, Central Asia and the Slav ex-USSR, while there is no significant relationship for the Baltics, Caucasus and Central Europe.

Concerning the Western European countries (the last column of Table 6), households affected by crisis 'a great deal' are more likely to bribe public officials (the marginal effect is five percentage points and the coefficients of other crisis dummies are insignificant). The marginal effect of the combined crisis dummy is much smaller (those affected by crisis 'a fair amount' or 'a great deal' are 1.2 percentage points more likely to bribe than those 'not at all' affected or affected 'just a little'). Overall, this finding is surprising, as one would not expect public officials in the West European countries to extort bribes from the users of public services. We have also analyzed the reasons why people pay bribes in the West but, contrary to the East, did not find any statistically significant effects of crisis on different motivations to bribe. It should also be noted that, relative to the East, a considerably smaller proportion of West European households reported that they were affected by crisis 'a great deal' (18.4 versus 9.5 percent) and that they bribed a public official (28.8 versus 4.6 percent of those who contacted public officials).

Panels III and IV of Table 6 show the relationship between the effects of the crisis and the number of different public officials bribed, which is estimated for the regional subsamples of respondents who bribed at least one public official. With the exception of the Baltics and Western Europe, crisis victims tend to bribe a wider range of public officials than the non-victims, although the effect is not always monotonic (households affected by crisis to a greater extent do not necessarily bribe a wider range of officials than households affected by crisis to a lesser extent). We re-run the model with the two combined crisis dummies and find that in the Balkans, Central Europe and Central Asia households affected by crisis 'a great deal' or 'a fair amount' bribe a wider range of public officials, and in other country groups the estimated coefficients are statistically insignificant. 
[Insert Table 6 here]

A contrast in the crisis-bribery relationship that we observe in Central Asia, on the one hand, and Central Europe and the Baltics, on the other, would suggest that the link between crisis and corruption is stronger in poorer countries. To test this conjecture, we run the models for high-income, uppermiddle income and a combined group of lower-middle-income and low-income countries (they are combined because only two countries are in the low-income group: Tajikistan and Kyrgyzstan). ${ }^{18}$ The results, presented in Table 7, suggest that in the low and lower-middle income countries households affected by crisis 'a great deal' are 15.1 percentage points more likely to bribe public officials and households affected by crisis 'a fair amount' and 'just a little' are ten percentage points more likely to do so. In upper-middle income countries, crisis victims are 5.0-7.8 percentage points more likely to bribe than the non-victims. In high-income countries, the crisis dummy coefficients are not statistically significant. Estimating the model with the two combined crisis dummies (results not reported) points in the same direction: relative to households that were not affected by crisis or affected 'just a little', households affected by crisis at least 'a fair amount' are 6.3 and 3.8 percentage points more likely to bribe public officials in low/ lower-middle income and upper-middle income countries, respectively; the coefficient in the high-income country group is insignificant.

The lower panel of Table 7 reports the results of the model explaining the number of different public officials bribed. Although the crisis dummies tend to be smaller and less significant in countries with higher GDPs per capita, the difference between country groups is not as strong as in the case of the bribery model. Replacing the four crisis dummies with two combined crisis dummies (results not reported in Table 7) suggests that households affected by crisis 'a fair amount' or 'a great deal' bribe, on average, 0.19 and 0.10 more public officials in the low and lower-middle income countries, while the coefficient for the upper-middle income countries is insignificant. To sum up, the results provide strong support for the hypothesis that crisis victims are more likely to bribe public officials in poorer

\footnotetext{
${ }^{18}$ The income groups were created according to the World Bank country income classification for 2009.
} 
countries; the evidence on whether in poorer countries crisis victims bribe a wider range of public officials is less clear-cut.

[Insert Table 7 here]

So far, our analysis has not distinguished between different types of public officials. However, it can be argued that crisis victims do not bribe all types of public officials in the same manner. For example, the conditions under which interaction with public officials takes place would determine whether crisis victims are more likely to bribe or not. Total interaction time could be important: for example, a road police officer would have insufficient time to ascertain if someone has been hit by crisis and thus be less able to extort. Public officials from other institutions can have more time (and, in many cases, are obliged) to collect information about their customers' jobs or salary histories - this could help inform their extortion decisions. Also, repeated interactions, which are less likely to occur for road police and more likely for other types of public officials, could be more conducive to extorting bribes from the crisis victims.

To test these conjectures, we have estimated the probability of bribery model for different types of public officials (Table 8). Being a crisis victim is associated with a greater likelihood of bribing all types of public officials, with the exception of courts. The largest effects are observed in the education, health and unemployment benefit specifications (households affected by crisis 'a great deal' are 8.3-9.4 percentage points more likely to bribe public officials than households that were not affected by crisis), followed by the requesting official documents and social security specifications (6.1-6.8 percentage points), and the smallest and less statistically significant effects are observed in the road police (3.8 percentage points) and the courts specification (marginal effect statistically insignificant). The effect of crisis on bribery is confirmed for all types of public officials, except the road police, when we replace the four crisis dummies with two (the lower panel of Table 8). The insignificant result for the road police supports the idea that interaction time and frequency of interactions are important for bribery. 
[Insert Table 8 here]

3.4. Crisis and bribery - endogeneity concerns

As mentioned in the beginning of this section, the results presented in this paper should be interpreted as conditional correlations and not causal effects. It is quite possible that certain groups of people and households are more likely to be hit by crisis than others, i.e., that an economic crisis hits people nonrandomly. For example, people working without an employment contract would be the first to be fired if the crisis forces a firm to scale down its activity. If people, who accept or are forced to work informally, also happen to be more prone to corruption, our results would suffer from the omitted variable bias and the estimated coefficients would not represent causal effect from crisis on bribery.

To mitigate potential endogeneity of the crisis variable, we estimated our main model with additional controls: a dummy variable for working in the income earner's primary occupation without a formal contract, and dummy variables for 26 sectors/ industries. The industry dummies were included because certain industries, such as construction, are more likely to employ informal workforces than, for example, public sector occupations (education, health). The inclusion of these controls did not change our results: compared to households which were not affected by crisis, those affected 'just a little', 'a fair amount' and 'a great deal' were more likely to bribe public officials, and, among those who paid at least one bribe, the crisis victims bribed more public officials.

While the inclusion of the informal work and industry dummies may help mitigate the endogeneity associated with omitted variables, it is not sufficient to claim causal effects of crisis on bribery. One way to control for unobserved household heterogeneity would be to use panel data and relate the change in household economic circumstances to the change in bribery experience. Another way to deal with endogeneity would be to use instruments - variables highly correlated with the probability of being a crisis victim but having no direct effect on the likelihood of bribing public officials. Because of data limitations, both the panel data and instrumental variable analyses are beyond the scope of this paper and represent an important direction of future research. 


\section{Conclusions}

This study has investigated possible household-level linkages between the effects of the 2008-09 economic crisis and corruption experience in the transition economies of Central and Eastern Europe and Central Asia. We found that, among those who have a contact with public officials, households affected by crisis are more likely to pay bribes. Also, among those who bribe, crisis victims tend to bribe a broader range of public officials than non-victims. The analysis of the reasons for bribery revealed that crisis victims are more likely than non-victims to bribe because they are asked to do so by public officials and less likely to bribe out of gratitude. This finding supports the conjecture that public officials misuse sensitive information about crisis victims (e.g., about their job history, savings, migrant connections) to inform bribe extortion decisions.

We find important differences in the crisis-bribery relationship in different country groups. It is in the poorer parts of the post-socialist world - Central Asia, Slav ex-USSR and the Balkans - that the crisis victims are more likely to bribe public officials, while there is no effect in wealthier parts of the region - Central Europe and the Baltics. The results are also not uniform across types of public officials: the crisis victims are more likely to bribe public health, education, and benefits officials, as well as officials dealing with issuing officials documents, but there is smaller difference between victims and non-victims when it comes to paying bribes to road police. This suggests that the conditions under which officials and crisis victims interact matter. Lengthier and, possibly, repeated interactions (which do not characterize encounters with road police) are more likely to be associated with bribery.

Overall, our results suggest that the victims of the economic crisis pay a double price - they experience declines in welfare owing to job loss, wage cuts or reductions in remittances - but they also pay more bribes, which further reduces their welfare. In the context of a broader literature on the determinants of corruption, our results suggest that a fall in material wellbeing is associated with a greater likelihood of being involved in bribery. This corroborates the finding of Hunt (2007) that the 
victims of misfortunes, such as job loss, robbery and business closure, are more likely to bribe public officials.

While the main focus of the paper was on the effects of crisis (a fall in household wellbeing relative to its past levels) on bribery, our analysis of control variables also revealed that it is people with a higher perceived income and greater wealth (relative to other households) who are more likely to bribe. This finding is consistent with the literature showing that better-off people are more prone to corruption (Guerrero and Rodriguez-Oreggia 2008; Hunt and Lazslo 2011; Mocan 2008; Gatti et al. 2003). Taken together, our study highlights the importance of different dimensions of household material wellbeing in explaining bribing behavior: both higher wealth and negative income shocks are likely to be associated with more corruption.

Acknowledgements

We thank the editors, two anonymous referees, and the conference participants at the Universities of Aston, Cambridge and Queen Mary for many useful comments and suggestions.

\section{References}

Barr, B., Taylor-Robinson, D., Scott-Samuel, A., McKee, M., \& Stuckler, D. (2012). Suicides associated with the 2008-10 economic recession in England: time trend analysis. British Medical Journal 345:e5142.

Dreher, A., \& Gassebner, M. (2013). Greasing the wheels? The impact of regulations and corruption on firm entry. Public Choice, 155, 413-432.

Dreher, A., \& Siemers, L. (2009). The nexus between corruption and capital account restrictions. Public Choice, 140, 245-265. 
Gili, M., Roca, M., Basu, S., McKee, M., \& Stuckler, D. (2013). The mental health risks of economic crisis in Spain: evidence from primary care centres, 2006 and 2010. European Journal of Public Health, 23, 103-08.

Hunt, J. (2007). How corruption hits people when they are down. Journal of Development Economics, 84(2), 574-589.

Hunt, J., \& Laszlo, S. (2012). Is bribery really regressive? Bribery's costs, benefits, and mechanisms. World Development, 40(2), 355-372.

Ivlevs, A., \& Hinks, T. (2014). Bribing behavior and sample selection: evidence from post-socialist countries and Western Europe. Journal of Economics and Statistics/ Jahrbücher für Nationalökonomie und Statistik (forthcoming).

Iwasaki, I., \& Suzuki, T. (2012). The determinants of corruption in transition economies. Economics Letters, 114, 54-60.

Johnson, N.D., LaFountain, C.L., \& Yamarik, S. (2011). Corruption is bad for growth (even in the United States). Public Choice, 147(3-4), 377-393.

Katikireddi, S.V., Niedzwiedz, C.L., \& Popham F. (2012). Trends in population mental health before and after the 2008 recession: a repeat cross-sectional analysis of the 1991-2010 Health Surveys of England. British Medical Journal Open, 2 (5), e001790.

Kaufmann, D., \& Wei, S-J. (2000). Does 'grease money' speed up the wheels of commerce? International Monetary Fund Policy Working Paper, WP/00/64.

Klitgaard, R. (1988). Controlling Corruption. (Berkeley: University of California Press).

Mauro, P. (1995). Corruption and growth. Quarterly Journal of Economics, 110, 681-712.

Méon, P-G., \& Sekkat, K. (2005). Does corruption grease or sand the wheels of growth? Public Choice, 122(1), 69-97.

Mendez, F. (2014). Can corruption foster regulatory compliance? Public Choice, 158, 189-207. 
Mocan, N. (2008). What determines corruption? International evidence from micro data. Economic Inquiry, 46(4), 493-510.

Priks, M. (2012). Competition among officials and the abuse of power. Public Choice, 150, 425-438.

Rose-Ackerman, S. (1978). Corruption. A Study in Political Economy. (New York: Academic Press)

Roth, F., Nowak-Lehmann, F., \& Otter, T. (2011). Has the financial crisis shattered citizens' trust in national and European governmental institutions? Evidence from the EU member states, 19992010. Centre for European Policy Studies Working Document.

Shleifer, A., \& Vishny, R. (1993). Corruption. Quarterly Journal of Economics, 108, 599-617.

Serra, D. (2006). Empirical determinants of corruption: A sensitivity analysis. Public Choice, 126, 225-256.

Sobotka, T.V., Skirbekk, V., \& Philipov, D. (2011). Economic recession and fertility in the developed world. Population and Development Review, 37(2), 267-306.

Steves, F. (Ed.). (2011). Life in transition: After the crisis. (London: European Bank for Reconstruction and Development \& World Bank).

Tavits, M. (2010). Why do people engage in corruption? The case of Estonia. Social Forces, 88(3), $1257-1279$.

Truex, R. (2011). Corruption, attitudes, and education: survey evidence from Nepal. World Development, 39(7), 1133-42.

Yamamura, E. (in press). Impact of natural disaster on public sector corruption. Public Choice. 
Table 1. The effects of the crisis on household income streams

\begin{tabular}{lcc}
\hline $\begin{array}{l}\text { How has the economic crisis affected you (or other household } \\
\text { members) in the past two years? }\end{array}$ & $\begin{array}{c}\text { Tick all that } \\
\text { apply (\%) }\end{array}$ & $\begin{array}{c}\text { Choose the most } \\
\text { important (\%) }\end{array}$ \\
\hline 1. Head of household lost job & 10.5 & 8.4 \\
2. Other household member lost job & 11.8 & 7.5 \\
3. Family business closed & 3.2 & 1.7 \\
4. Working hours reduced & 8.1 & 2.9 \\
5. Wages delayed or suspended & 13.1 & 5.9 \\
6. Wages reduced & 29.3 & 20.1 \\
7. Reduced flow of remittances & 13.6 & 8.5 \\
8. Family members returned home from abroad & 2.7 & 1.2 \\
9. Someone who was working took on a second job & 4.2 & 1.5 \\
10. Increased working hours in an existing job & 5.6 & 2.1 \\
11. Someone who was not working before found a new job & 2.9 & 1.5 \\
\hline
\end{tabular}

Source: Life in Transition-2 survey.

Table 2. In the past two years, have you or anyone else in your household had to take any of the following measures as the result of a decline in income or other economic difficulty?

\begin{tabular}{lc}
\hline Measure & $\begin{array}{c}\text { Proportion of } \\
\text { households (\%) }\end{array}$ \\
\hline Reduced consumption of staple goods & 38.3 \\
Reduced consumption of luxury goods & 44.9 \\
Reduced consumption of alcohol & 16.7 \\
Reduced use of own car & 16.4 \\
Reduced vacations & 22.8 \\
Reduced tobacco smoking & 11.6 \\
Postponed/withdrew from university & 2.8 \\
Enrolled in further education because of lack of job opportunities & 2.1 \\
Postponed/withdrew from training course & 2.6 \\
Postponed/skipped visits to the doctor after falling ill & 12.7 \\
Cancelled health insurance & 2.9 \\
Stopped buying regular medications & 10.0 \\
Stopped/reduced help to relatives who you helped before & 9.3 \\
Delayed payment on utilities & 16.3 \\
Had utilities cut because of delayed payment & 4.2 \\
Cut TV/phone/internet & 5.9 \\
Delayed or defaulted on a loan instalment & 3.5 \\
Sold an asset & 2.8 \\
Was forced to move & 1.3 \\
\hline
\end{tabular}

Source: Life in Transition-2 survey. 
Table 3. The determinants of the probability of bribing public officials and the number of officials

bribed

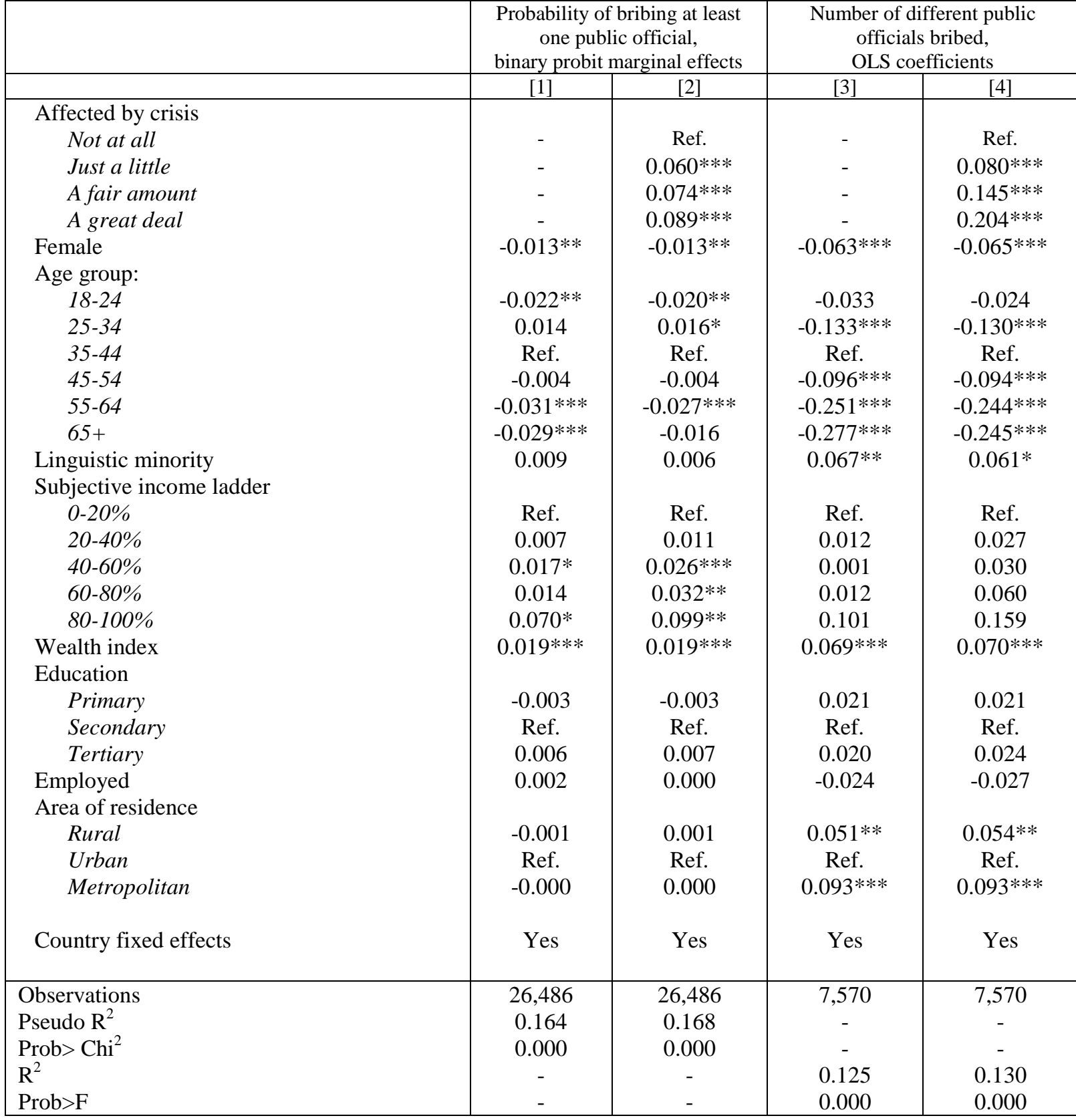

Notes: $* p<0.10, * * p<0.05, * * * p<0.01$. Robust standard errors used to calculate regressors' level of significance. Marginal effects in specifications [1] and [2] are calculated at the variable means. 
Table 4. Crisis impacts on household income streams and expenditures and bribery

\begin{tabular}{|c|c|c|c|c|c|c|}
\hline & \multicolumn{3}{|c|}{$\begin{array}{c}\text { Probability of bribery, } \\
\text { binary probit marginal effects }\end{array}$} & \multicolumn{3}{|c|}{$\begin{array}{l}\text { The number of different public } \\
\text { officials bribed, OLS coefficients }\end{array}$} \\
\hline & [1] & {$[2]$} & {$[3]$} & {$[4]$} & [5] & {$[6]$} \\
\hline \multicolumn{7}{|l|}{ Effects on income streams } \\
\hline Head of household lost job & $0.030 * * *$ & $0.064 * * *$ & - & $0.137 * * *$ & $0.212 * * *$ & - \\
\hline Other household member lost job & $0.045^{* * *}$ & $0.076 * * *$ & - & $0.083 * *$ & $0.172 * * *$ & - \\
\hline Family business closed & $0.043 * * *$ & $0.081 * * *$ & - & $0.207 * * *$ & $0.261 * * *$ & - \\
\hline Working hours reduced & $0.045^{* * *}$ & $0.075 * * *$ & - & $0.080 * *$ & $0.130 * *$ & - \\
\hline Wages delayed or suspended & $0.040 * * *$ & $0.078 * * *$ & - & $0.077 * * *$ & $0.092 * *$ & - \\
\hline Wages reduced & $0.036 * * *$ & $0.054 * * *$ & - & $0.120 * * *$ & $0.120 * * *$ & - \\
\hline Reduced flow of remittances & $0.046^{* * *}$ & $0.072 * * *$ & - & $0.081 * *$ & $0.084 * *$ & - \\
\hline Migrant returned home from & $0.058 * * *$ & $0.092 * * *$ & - & $0.179 * * *$ & 0.115 & - \\
\hline \multicolumn{7}{|l|}{ abroad } \\
\hline \multicolumn{7}{|l|}{ Effects on expenditures } \\
\hline Reduced staple goods & - & - & -0.001 & - & - & -0.007 \\
\hline Reduced luxuries & - & - & $0.027 * * *$ & - & - & -0.016 \\
\hline Reduced car & - & - & $0.030 * * *$ & - & - & $0.160 * * *$ \\
\hline Reduced vacations & - & - & $0.037 * * *$ & - & - & 0.024 \\
\hline Reduced alcohol/smoking & - & - & -0.005 & - & - & $0.047 *$ \\
\hline Effects on education & - & - & $0.040 * * *$ & - & - & $0.196^{* * *}$ \\
\hline Effects on medical expenditures & - & - & $0.063 * * *$ & - & - & $0.074 * * *$ \\
\hline Effects on utilities & - & - & $0.040 * * *$ & - & - & 0.042 \\
\hline Effects on assets/loans/move & - & - & $0.052 * * *$ & - & - & $0.094 * *$ \\
\hline Observations & 26,486 & 26,486 & 26,486 & 7,570 & 7,570 & 7,570 \\
\hline Pseudo $\mathrm{R}^{2}$ & 0.171 & 0.168 & 0.176 & - & - & - \\
\hline Prob $>\mathrm{Chi}^{2}$ & 0.000 & 0.000 & 0.000 & - & - & - \\
\hline $\mathrm{R}^{2}$ & - & - & - & 0.141 & 0.131 & 0.139 \\
\hline Prob $>F$ & - & - & - & 0.000 & 0.000 & 0.000 \\
\hline
\end{tabular}

Notes: $* p<0.10, * * p<0.05, * * * p<0.01$. Robust standard errors used to calculate regressors' level of significance. Marginal effects in columns [1]-[3] are estimated at regressor means. All regressions include the same controls as in Table 3. 
Table 5. Effects of crisis and reasons to paying bribes, multinomial logit marginal effects

\begin{tabular}{cr}
\hline Reason: I was asked to pay & Ref. \\
Affected by crisis & $-0.033^{* *}$ \\
Not at all & 0.021 \\
Just a little & $0.068^{* * *}$ \\
A fair amount & Ref. \\
A great deal & -0.012 \\
Reason: I was not asked to pay but I knew that an informal payment was expected & -0.005 \\
Affected by crisis & -0.016 \\
Not at all & Ref. \\
Just a little & 0.021 \\
A fair amount & -0.001 \\
A great deal & 0.001 \\
\hline Reason: I offered to pay, to get things done better and quicker & Ref. \\
Affected by crisis & 0.020 \\
Not at all & $-0.025^{* *}$ \\
Just a little & $-0.053^{* * *}$ \\
A fair amount & 11,945 \\
A great deal & 7,567 \\
Affected by crisis & 0.000 \\
Not at all & 0.11 \\
Just a little & \\
A fair amount & \\
A great deal & \\
\hline Number of bribery episodes & \\
Number of households & \\
Prob $>$ Chi ${ }^{2}$ & Pseudo R \\
\hline Reason: was not asked to pay, but I wanted to express my gratitude & \\
\hline
\end{tabular}

Notes: $* p<0.10, * * p<0.05$, *** $p<0.01$. Unit of analysis: household-official bribery episode. Marginal effects calculated at variable means. Standard errors clustered are at household level. The same controls as in Table 3 are included; the regression also includes dummies for public officials. 
Table 6. General effects of crisis and bribery, by geopolitical region.

\begin{tabular}{|c|c|c|c|c|c|c|c|}
\hline & 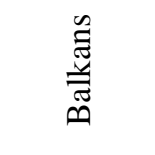 & $\frac{\mathscr{e}}{\stackrel{\mathscr{E}}{\pi}}$ & $\begin{array}{l}\tilde{E} \\
\tilde{\Xi} \\
\tilde{U} \\
\tilde{E} \\
\tilde{E}\end{array}$ & 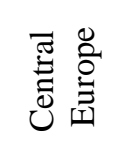 & 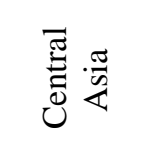 & 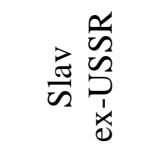 & 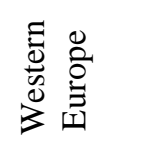 \\
\hline \multicolumn{8}{|c|}{$\begin{array}{l}\text { I. Dependent variable: probability of bribery } \\
\text { Affected by crisis }\end{array}$} \\
\hline Not at all & Ref. & Ref. & Ref. & Ref. & Ref. & Ref. & Ref. \\
\hline Just a little & $0.044 * * *$ & -0.003 & $0.073^{*}$ & 0.016 & $0.149 * * *$ & $0.044^{*}$ & 0.003 \\
\hline A fair amount & $0.044 * * *$ & 0.010 & $0.062 * *$ & 0.021 & $0.190 * * *$ & $0.070 * * *$ & 0.003 \\
\hline A great deal & $0.043 * * *$ & 0.014 & $0.061 *$ & $0.037 *$ & $0.271 * * *$ & $0.082 * *$ & $0.050 * * *$ \\
\hline Pseudo $\mathrm{R}^{2}$ & 0.139 & 0.0903 & 0.396 & 0.0913 & 0.121 & 0.102 & 0.133 \\
\hline Prob $>\mathrm{Chi}^{2}$ & 0.000 & 0.000 & 0.000 & 0.000 & 0.000 & 0.000 & 0.000 \\
\hline Observations & 8,018 & 2,370 & 2,398 & 4,046 & 3,854 & 3,384 & 3,787 \\
\hline \multicolumn{8}{|c|}{$\begin{array}{l}\text { II. Dependent variable: probability of bribery } \\
\text { Affected by crisis }\end{array}$} \\
\hline Not at all/ just a little & Ref. & Ref. & Ref. & Ref. & Ref. & Ref. & Ref. \\
\hline A fair amount/ a great deal & $0.025 * * *$ & 0.014 & 0.036 & 0.015 & $0.162 * * *$ & $0.052 * * *$ & $0.012 * *$ \\
\hline Pseudo $\mathrm{R}^{2}$ & 0.135 & 0.0898 & 0.389 & 0.0863 & 0.0914 & 0.0999 & 0.117 \\
\hline Prob $>\mathrm{Chi}^{2}$ & 0.000 & 0.000 & 0.000 & 0.000 & 0.000 & 0.000 & 0.000 \\
\hline Observations & 8,018 & 2,370 & 2,398 & 4,046 & 3,854 & 3,384 & 3,787 \\
\hline \multicolumn{8}{|c|}{$\begin{array}{l}\text { III. Dependent variable: Number of officials bribed } \\
\text { Affected by crisis }\end{array}$} \\
\hline Not at all & Ref. & Ref. & Ref. & Ref. & Ref. & Ref. & Ref. \\
\hline Just a little & $0.196 * * *$ & 0.015 & $0.329 * * *$ & 0.003 & -0.036 & $0.112 *$ & 0.048 \\
\hline A fair amount & $0.166^{* * *}$ & 0.064 & 0.116 & 0.121 & $0.248 * * *$ & $0.105^{*}$ & 0.131 \\
\hline A great deal & $0.168 * * *$ & 0.118 & $0.226^{* *}$ & 0.090 & $0.383 * * *$ & $0.149 * *$ & 0.354 \\
\hline $\mathrm{R}^{2}$ & 0.128 & 0.119 & 0.119 & 0.164 & 0.095 & 0.106 & 0.288 \\
\hline Prob $>\mathrm{F}$ & 0.000 & 0.000 & 0.000 & 0.000 & 0.000 & 0.000 & 0.000 \\
\hline Observations & 1,669 & 566 & 901 & 612 & 1,898 & 1,336 & 177 \\
\hline \multicolumn{8}{|c|}{$\begin{array}{l}\text { IV. Dependent variable: number of officials bribed } \\
\text { Affected by crisis }\end{array}$} \\
\hline Not at all/ just a little & Ref. & Ref. & Ref. & Ref. & Ref. & Ref. & Ref. \\
\hline A fair amount/ a great deal & $0.083 *$ & 0.070 & 0.013 & $0.109 *$ & $0.316 * * *$ & 0.060 & 0.195 \\
\hline $\mathrm{R}^{2}$ & 0.124 & 0.118 & 0.107 & 0.163 & 0.0932 & 0.103 & 0.282 \\
\hline Prob $>$ F & 0.000 & 0.000 & 0.000 & 0.000 & 0.000 & 0.000 & 0.000 \\
\hline Observations & 1,669 & 566 & 901 & 612 & 1,898 & 1,336 & 177 \\
\hline
\end{tabular}

Notes: $* p<0.10, * * p<0.05, * * * p<0.01$. Robust standard errors used to calculate regressors' level of significance. The same controls as in table 3 are included in all regressions. 


\begin{tabular}{|c|c|c|c|}
\hline & $\begin{array}{l}\text { Low and } \\
\text { lower-middle } \\
\text { income } \\
\text { countries }\end{array}$ & $\begin{array}{l}\text { Upper-middle } \\
\text { income } \\
\text { countries }\end{array}$ & $\begin{array}{l}\text { High-income } \\
\text { countries }\end{array}$ \\
\hline \multicolumn{4}{|c|}{ I. Dependent variable: probability of bribery } \\
\hline \multicolumn{4}{|c|}{ Affected by crisis } \\
\hline Not at all & Ref. & Ref. & Ref. \\
\hline Just a little & $0.102 * * *$ & $0.050 * * *$ & 0.013 \\
\hline A fair amount & $0.100 * * *$ & $0.078 * * *$ & 0.011 \\
\hline A great deal & $0.151 * * *$ & $0.072 * * *$ & 0.015 \\
\hline Pseudo $\mathrm{R}^{2}$ & 0.183 & 0.132 & 0.0807 \\
\hline Prob $>\mathrm{Chi}^{2}$ & 0.000 & 0.000 & 0.000 \\
\hline Observations & 9,195 & 11,699 & 5,592 \\
\hline \multicolumn{4}{|c|}{$\begin{array}{l}\text { II. Dependent variable: number of public officials bribed } \\
\text { Affected by crisis }\end{array}$} \\
\hline Not at all & Ref. & Ref. & Ref. \\
\hline Just a little & 0.041 & $0.146 * * *$ & 0.022 \\
\hline A fair amount & $0.212 * * *$ & $0.093 * * *$ & $0.119^{*}$ \\
\hline A great deal & $0.261 * * *$ & $0.174 * * *$ & 0.103 \\
\hline $\mathrm{R}^{2}$ & 0.0941 & 0.120 & 0.160 \\
\hline Prob $>$ F & 0.000 & 0.000 & 0.000 \\
\hline Observations & 3,515 & 3,306 & 749 \\
\hline
\end{tabular}

Notes: Robust standard errors used to calculate regressors' level of significance. The same controls as in Table 3 are included in all regressions. $* p<0.10, * * p<0.05, * * * p<0.01$.

Table 8. General effects of crisis and bribery, by type of public official/institution

|

\begin{tabular}{|c|c|c|c|c|c|c|c|c|}
\hline \multicolumn{9}{|c|}{$\begin{array}{l}\text { I. Dependent variable: probability of bribery } \\
\text { Affected by crisis }\end{array}$} \\
\hline Not at all & Ref. & Ref. & Ref. & Ref. & Ref. & Ref. & Ref. & Ref. \\
\hline Just a little & $0.034 *$ & $0.043 * * *$ & 0.003 & $0.055 * * *$ & $0.040 * * *$ & $0.064 * * *$ & $0.078 * * *$ & $0.048 * * *$ \\
\hline A fair amount & $0.037 * *$ & $0.058 * * *$ & $0.052 * *$ & $0.060 * * *$ & $0.054 * * *$ & $0.071 * * *$ & $0.051 * *$ & $0.055 * * *$ \\
\hline A great deal & $0.038 *$ & $0.068 * * *$ & 0.036 & $0.083 * * *$ & $0.092 * * *$ & $0.094 * * *$ & $0.094 * * *$ & $0.061 * * *$ \\
\hline Pseudo $\mathrm{R}^{2}$ & 0.251 & 0.271 & 0.249 & 0.220 & 0.234 & 0.172 & 0.197 & 0.194 \\
\hline Prob $>\mathrm{Chi}^{2}$ & 0.000 & 0.000 & 0.000 & 0.000 & 0.000 & 0.000 & 0.000 & 0.000 \\
\hline Number of observations & 6,157 & 7,547 & 1,434 & 8,327 & 5,189 & 22,501 & 1,755 & 3,085 \\
\hline \multicolumn{9}{|c|}{$\begin{array}{l}\text { II. Dependent variable: Probability of bribery } \\
\text { Affected by crisis }\end{array}$} \\
\hline Not at all/ just a little & Ref. & Ref. & Ref. & Ref. & Ref. & Ref. & Ref. & Ref. \\
\hline A fair amount/ a great deal & 0.020 & $0.038 * * *$ & $0.039 * *$ & $0.037 * * *$ & $0.043 * * *$ & $0.046^{* * *}$ & $0.025 * *$ & $0.027 * * *$ \\
\hline Pseudo $\mathrm{R}^{2}$ & 0.251 & 0.269 & 0.249 & 0.216 & 0.231 & 0.169 & 0.185 & 0.190 \\
\hline Prob $>\mathrm{Chi}^{2}$ & 0.000 & 0.000 & 0.000 & 0.000 & 0.000 & 0.000 & 0.000 & 0.000 \\
\hline Number of observations & 6,157 & 7,547 & 1,434 & 8,327 & 5,189 & 22,501 & 1,755 & 3,085 \\
\hline
\end{tabular}

Notes: $* \mathrm{p}<0.10, * * \mathrm{p}<0.05, * * * \mathrm{p}<0.01$. Robust standard errors used to calculate regressors' level of significance. The same controls as in Table 3 are included in all regressions. 